\title{
Contribution of tidal submergence to phosphorus nutrition and yield of rice
}

\author{
M.A. Haque \\ Department of Soil Science, Patuakhali Science and Technology University, Dumki, Patuakhali-8600
}

\begin{abstract}
Two pot and two field experiments were conducted at Patuakhali Science and Technology University research farm to investigate the contribution of tidal submergence to phosphorus nutrition and yield of rice. Pot and field experiments were conducted in the Aus and Aman seasons of 2009, respectively. The factorial experiments include two levels of water source- i) tidal water and ii) ground water, and three levels of fertilizers- i) absolute control (no fertilizer), ii) NK (P omission) and iii) NPK (P addition). The rice varieties used were BRRI dhan27 (HYV) and Local Mala (Traditional variety) in Aus season and BR23 (HYV) and Lalmota (Traditional variety) in Aman season. A general increase in growth, yield and yield contributing parameters were found due to irrigation with tidal water. Tidal water contributed about 21 (BR23) and 7 (Lalmota) \% higher grain yield in Aman season 2009 and about $2 \mathrm{~g}$ biomass yield per pot (both BRRI dhan27 and Local Mala) in Aus season of 2009 compared to ground water. Phosphorus content of rice grain and straw was always higher when plants are irrigated with tidal water. In general tidal submergence increases $\mathrm{P}$ uptake of rice. Phosphorus uptake from tidal water treatments increased when plants were supplied with $\mathrm{N}$ and $\mathrm{K}$ fertilizer. Tidal submergence contributed about 5-6 kg P/ha in $\mathrm{P}$ omission plot, and about $12-14$ $\mathrm{kg} \mathrm{P} / \mathrm{ha}$ in plots with added $\mathrm{P}$.
\end{abstract}

Keywords: Phosphorus, Rice, Tidal submergence

\section{Introduction}

Phosphorus mining from the soils is a serious problem of Bangladesh resulting substantial decrease in available $P$ (Ali et al., 1997). The general recommended dose of $P$ fertilizer for high yielding rice in Bangladesh is $15-20 \mathrm{~kg} \mathrm{P}^{-1}$ (FRG, 2005). However, many farmers of the country do not apply $P$ fertilizer to rice, as $\mathrm{P}$ deficiency symptoms are not as conspicuous as observed for $\mathrm{N}$ deficiency. Nevertheless, inappropriate $P$ fertilizer management coupled with increasing cropping intensity with modern HYV led $P$ deficiency in many alluvial soils of Bangladesh. Omission of $P$ fertilizer in rice-rice cropping systems may lower available $P$ content in soil, resulting lower yield of rice (Saleque et al., 1998). Huge effort is given to develop $P$ management strategy in high and medium high lands. However, less attention is made for $\mathrm{P}$ management in coastal tidal lands of Bangladesh. Farmers are very much reluctant to use $P$ for rice production in this region. Coastal tidal lands are characterized by tidal inundation twice in a day. Tidal water carry huge amount of sediments which are expected to deposit in the rice field. Tidal sediments are an important source of primary, secondary and micro nutrients to tidal flooded soil. Nitrogen in the sediments is linked mainly to organic matter. Phosphorus, potassium and others are primarily associated with fine-grained clay minerals (Odum, 1988). Sediment deposition plays a critical role in the sustainable production of rice in the southern coastal tidal soils of Bangladesh, because tidal water increases plant height, tiller production, shoot weight, and nitrogen concentration and uptake of rice (Haque et al., 2008). Velocity and duration of flooding can influence sediment deposition and hence nutrient availability in tidal fresh water marshes (Darke and Megonigal, 2003). Sedimentation in tidal areas is generally highest during rainy-season when high river discharge and current of water increases riverbank erosion, fully covered rice field traps sediment on the tidal flooded marshes, nutrient uptake also increased as well (Morse et al., 2004). Moreover, the tidal water may contain soluble nutrients which may contribute to the nutrition of rice. Hence, this situation a research is seeking to quantify how much contribution can tidal submergence made to nutrition of rice. The study was therefore undertaken to know the contribution of tidal submergence to phosphorus nutrition of rice. 


\section{Materials and Methods}

Four experiments- two in Aus season and two in Aman season of 2009 were conducted at Patuakhali Science and Technology University research farm. The experiments of Aus season were conducted in pots and that of Aman season in fields. Each experiment includes two factors; first factor 'source of irrigation water' consisting two levels: i) tidal water and ii) ground water, second factor 'fertilizer' consisting three levels: i) absolute control (no fertilizer), ii) NK (P omission) and iii) NPK (P addition). Thus six treatment combinations were used in the experiments. Each treatment was replicated three times. In Aus season, BRRI dhan27 was used in one experiment and a local variety Mala was used in other experiment. In Aman season, BR23 was used in one experiment and Local Lalmota was used in another experiment.

In case of pot experiments, six $\mathrm{kg}$ soil was taken in each of 18 pots. The initial soil contains $0.14 \%$ total $\mathrm{N}$, $1.5 \mathrm{ppm}$ available phosphorus, $0.28 \mathrm{me} / 100 \mathrm{~g}$ soil exchangeable potassium, $78.3 \mathrm{ppm}$ available S, $2.84 \%$ organic matter and $\mathrm{pH}$ of 5.4. The sprouted seeds of the rice varieties were sown on 06.5.2009 on puddled soil in such a way that each pot received four hills and each hill received 3 adequately sprouted seeds. Fertilizer application was made with 100,10 and $40 \mathrm{mg} / \mathrm{kg}$ soil of $\mathrm{N}, \mathrm{P}$ and $\mathrm{K}$, respectively. Phosphorus and $\mathrm{K}$ were applied during puddling and $\mathrm{N}$ was applied in two equal splits at 15 and 30 days after sowing. Fertilizers were allocated according to the treatments. Adequate amount of tidal and ground water was applied in each pot according to the treatment to nourish the crop. After 50 days of sowing the plants were harvested and subsequent physical and chemical data were recorded.

The initial soil of the field experiments contains $0.09 \%$ total $\mathrm{N}, 12.6 \mathrm{ppm}$ available phosphorus, 0.39 me $/ 100 \mathrm{~g}$ soil exchangeable potassium, $46.5 \mathrm{ppm}$ available $\mathrm{S}, 1.72 \%$ organic matter and $\mathrm{pH}$ of 7.5 . Thirty five days old seedlings were transplanted on $3^{\text {rd }}$ September 2009 with the plant spacing of $20 \times 20 \mathrm{~cm}$. Three to four seedlings were transplanted in each hill. Fertilizer application was made with 80, 20 and 60 $\mathrm{kg} / \mathrm{ha}$ of $\mathrm{N}, \mathrm{P}$ and $\mathrm{K}$, respectively as per the treatments. Phosphorus and $\mathrm{K}$ were applied during puddling and $\mathrm{N}$ was applied in two equal splits at 15 and 30 days after transplanting. Irrigation was done with tidal and deep tube-well water. Plants were harvested at maturity and subsequent measurement of plant height, tillers/hill, grains/panicle and grain and straw yield was done. Chemical analysis of grain and straw were done using standard methods. The data obtained in the experiments were statistically analysed using MSTAT computer software program.

\section{Results and Discussion}

\section{Pot experiments}

Plant height and number of tillers per hill of both BRRI dhan27 and local Mala were not significantly influenced by water sources (Table 1). However, it was strongly influenced by fertilizer treatments over both the varieties. Although not significant but 3 and $5 \%$ higher plant height, and 4 and $8 \%$ higher number of tillers were recorded (Table 1 ) by tidal water compared to ground water treatments with the varieties BRRI dhan27 and Local Mala, respectively. Similar trend was also reported by Haque et al. (2008). They reported $12 \%$ higher plant height and about double tillers by tidal water over ground water. Among the fertilizer treatments NPK receiving plots recorded the highest of 91 and $82 \mathrm{~cm}$ plant height, and 6 and 9 tillers per hill by the variety BRRI dhan27 and local Mala, respectively (Table 1). Interaction effect among sources of irrigation water and fertilizer was not significant. Tiller production ability seems to be higher in local Mala compared to BRRI dhan27. About 11 and $8 \mathrm{~g} /$ pot dry biomass was recorded by tidal water in BRRI dhan27 and Mala, respectively, while the values were 10 and $6 \mathrm{~g} / \mathrm{pot}$ with groundwater (Table 1). Haque et al. (2008) reported about double biomass by tidal water compared to ground water. Among the fertilizer treatments NPK received pots recorded the highest yield with both the varieties. Interaction effect of tidal water and fertilizers always gave higher biomass yield compared to ground water and fertilizers. 
Table 1. Plant height (cm), tillers/hill, biomass yield (g/pot) and phosphorus content (\%) of rice varieties as influenced by irrigation water sources and fertilizers, Aus 2009

\begin{tabular}{|c|c|c|c|c|c|c|c|c|}
\hline \multirow[t]{2}{*}{ Treatments } & \multicolumn{2}{|c|}{ Plant height } & \multicolumn{2}{|c|}{ Tillers/hill } & \multicolumn{2}{|c|}{ Biomass yield } & \multicolumn{2}{|c|}{ Phosphorus content } \\
\hline & BR27 & Mala & BR27 & Mala & BR27 & Mala & BR27 & Mala \\
\hline \multicolumn{9}{|l|}{ Irrigation } \\
\hline Tidal water & 79.0 & 70.1 & 4.36 & 5.87 & $10.740 \mathrm{a}$ & $8.169 \mathrm{a}$ & $0.234 \mathrm{a}$ & $0.269 \mathrm{a}$ \\
\hline Ground water & 76.9 & 66.7 & 4.19 & 5.42 & $9.431 \mathrm{~b}$ & $5.887 \mathrm{~b}$ & $0.204 \mathrm{~b}$ & $0.223 \mathrm{~b}$ \\
\hline \multicolumn{9}{|l|}{ Fertilizer } \\
\hline Control & $57.3 \mathrm{c}$ & $56.5 \mathrm{c}$ & $3.04 \mathrm{c}$ & $3.33 \mathrm{c}$ & $3.629 \mathrm{c}$ & $3.153 \mathrm{c}$ & $0.219 \mathrm{~b}$ & 0.250 \\
\hline $\mathrm{P}$ omission (NK) & $85.5 \mathrm{~b}$ & $66.8 \mathrm{~b}$ & $3.71 \mathrm{~b}$ & $5.00 \mathrm{~b}$ & $9.653 \mathrm{~b}$ & $4.777 \mathrm{~b}$ & $0.174 \mathrm{c}$ & 0.247 \\
\hline NPK & $91.0 \mathrm{a}$ & $81.8 \mathrm{a}$ & $6.08 \mathrm{a}$ & $8.59 \mathrm{a}$ & $16.974 \mathrm{a}$ & $13.154 \mathrm{a}$ & $0.309 \mathrm{a}$ & 0.309 \\
\hline \multicolumn{9}{|l|}{ Irrigation $\times$ Fertilizer } \\
\hline Tidal water $\times$ Control & 57.0 & 56.7 & 3.08 & 3.33 & 3.772 & $3.058 \mathrm{~d}$ & $0.219 \mathrm{~b}$ & 0.250 \\
\hline Tidal water $\times \mathrm{P}$ omission & 87.0 & 69.3 & 3.83 & 5.08 & 10.602 & $5.522 \mathrm{c}$ & $0.174 \mathrm{c}$ & 0.247 \\
\hline Tidal water $\times$ NPK & 93.0 & 84.3 & 6.17 & 9.18 & 17.845 & $15.926 \mathrm{a}$ & $0.309 a$ & 0.309 \\
\hline Ground water $\times$ Control & 57.7 & 56.3 & 3.00 & 3.33 & 3.485 & $3.247 \mathrm{~d}$ & $0.205 \mathrm{~b}$ & 0.207 \\
\hline Ground water $\times \mathrm{P}$ omission & 84.0 & 64.3 & 3.58 & 4.92 & 8.705 & $4.032 \mathrm{~cd}$ & $0.102 \mathrm{~d}$ & 0.205 \\
\hline Ground water×NPK & 89.0 & 79.3 & 6.00 & 8.00 & 16.102 & $10.382 \mathrm{~b}$ & $0.305 \mathrm{a}$ & 0.257 \\
\hline
\end{tabular}

Common letters in a column are not significantly different at $5 \%$ level by DMRT

Phosphorus content of BRRI dhan27 and local Mala was significantly influenced by both irrigation water sources and fertilizers. Tidal water treatments recorded 0.23 and $0.27 \%$ phosphorus in BRRI dhan27 and Mala respectively, whereas the values were 0.20 and $0.22 \%$ with ground water. Table 1 shows that tidal water contributed $0.03 \%$ more phosphorus in BRRI dhan27 and that of $0.046 \%$ in local Mala over ground water treatment. Among the fertilizer treatments NPK treated pots recorded the highest phosphorus content in both the varieties (Table 1). Interaction effect between tidal water and NPK fertilizer gave highest of $0.31 \%$ phosphorus where as lowest of $0.10 \%$ phosphorus was recorded by BRRI dhan27 in ground water $\times$ phosphorus omission interaction. When BRRI dhan27 are irrigated with tidal water, they uptake $0.001,0.009$, and $0.006 \mathrm{~g} /$ pot higher $\mathrm{P}$ from absolute control, $\mathrm{P}$ omission and $\mathrm{P}$ added pots, whereas it was $0.001,0.006$ and 0.022 in local Mala (Fig. 1), respectively. From the results it is shown that in control condition (no fertilizer) the increase in $\mathrm{P}$ uptake due to tidal submergence is negligible. When plants received $\mathrm{N}$ and $\mathrm{K}$ along with $\mathrm{P}$ omission or $\mathrm{P}$ addition remarkable variation in $\mathrm{P}$ uptake due to tidal submergence is noticed.

\section{Field experiments}

Plant height of BR23 was significantly influenced by irrigation water sources but it was insignificant in local Lalmota (Table 2). Higher plant height was recorded by tidal water compared to ground water. Table 2 shows that 2.4 and $1.7 \mathrm{~cm}$ plant height benefit was recorded due to tidal submergence in BR23 and Lalmota, respectively. Among the fertilizer treatments NPK treated plots gave the highest plant height in both the varieties; however it was statistically identical with that of P omission plot of BR23. Tidal water significantly increased the number of tillers per square meter in BR23 but not in Lalmota. Table 2 shows that tidal submergence contributed about 25 and 18 numbers of higher tillers per square meter in BR23 and Lalmota, respectively compared to ground water. Regarding fertilizer treatments omission or addition of $P$ produce statistically identical number of tillers per square meter.

Filled grains per panicle of BR23 and Lalmota were not significantly influenced by irrigation water sources, but $13 \%$ higher number of grains per panicle was recorded by BR23 due to tidal water treatment. Table 2 shows that addition or omission of $P$ produced identical number of grains per panicle. Grain production capacity was found higher in BR23 compared to Lalmota. Percent sterility was significantly influenced by irrigation water sources in BR23 but was not significant in local Lalmota (Table 3). Twenty four and 16 percent less sterility was found in tidal water treatments compared to ground water in the varieties BR23 and Lalmota, respectively. Among the fertilizer treatments there were found no significant difference in percent sterility over both rice varieties. Thousand grain weight of two rice varieties was not significantly influenced by irrigation water sources but it was significantly influenced by fertilizer treatments. Table 3 shows that $\mathrm{P}$ omission or addition gave identical grain weight. 
Table 2. Plant height $(\mathrm{cm})$, tillers/hill and biomass yield (g/pot) of rice varieties as influenced by irrigation water sources and fertilizers, Aman 2009

\begin{tabular}{|c|c|c|c|c|c|c|}
\hline \multirow[t]{2}{*}{ Treatments } & \multicolumn{2}{|c|}{ Plant height } & \multicolumn{2}{|c|}{ Tillers/sq.m } & \multicolumn{2}{|c|}{ Filled grains/panicle } \\
\hline & BR23 & Lalmota & BR23 & Lalmota & BR23 & Lalmota \\
\hline \multicolumn{7}{|l|}{ Irrigation } \\
\hline Tidal water & $110.6 \mathrm{a}$ & 130.0 & $194.7 \mathrm{a}$ & 195.1 & 119.9 & 68.2 \\
\hline Ground water & $108.2 \mathrm{~b}$ & 128.3 & $169.4 \mathrm{~b}$ & 176.7 & 106.0 & 68.8 \\
\hline \multicolumn{7}{|l|}{ Fertilizer } \\
\hline Control & $104.5 \mathrm{~b}$ & $120.3 \mathrm{c}$ & $153.7 \mathrm{~b}$ & $127.2 \mathrm{~b}$ & $96.2 \mathrm{~b}$ & $63.3 \mathrm{~b}$ \\
\hline $\mathrm{P}$ omission (NK) & $111.7 \mathrm{a}$ & $131.7 \mathrm{~b}$ & $193.8 \mathrm{a}$ & $217.3 \mathrm{a}$ & $122.5 \mathrm{a}$ & $67.1 \mathrm{ab}$ \\
\hline NPK & $112.0 \mathrm{a}$ & $135.5 \mathrm{a}$ & $198.7 \mathrm{a}$ & $213.2 \mathrm{a}$ & $120.2 \mathrm{a}$ & $75.0 \mathrm{a}$ \\
\hline \multicolumn{7}{|l|}{ Irrigation $\times$ Fertilizer } \\
\hline Tidal water $\times$ Control & $105.7 \mathrm{de}$ & 123.3 & 169.0 & $159.3 \mathrm{~b}$ & 109.7 & $59.3 \mathrm{~b}$ \\
\hline Tidal water $\times \mathrm{P}$ omission & $110.3 \mathrm{bc}$ & 131.0 & 213.7 & $218.0 \mathrm{a}$ & 126.1 & $62.8 \mathrm{~b}$ \\
\hline Tidal water $\times$ NPK & $115.7 \mathrm{a}$ & 135.7 & 201.3 & $208.0 \mathrm{a}$ & 124.0 & $82.4 \mathrm{a}$ \\
\hline Ground water $\times$ Control & $103.3 \mathrm{e}$ & 117.3 & 138.3 & $95.0 \mathrm{c}$ & 82.7 & $67.3 \mathrm{~b}$ \\
\hline Ground water $\times \mathrm{P}$ omission & $113.0 \mathrm{ab}$ & 132.3 & 174.0 & $216.7 \mathrm{a}$ & 118.9 & $71.4 \mathrm{ab}$ \\
\hline Ground water×NPK & $108.3 \mathrm{~cd}$ & 135.3 & 196.0 & $218.3 \mathrm{a}$ & 116.4 & $67.6 \mathrm{~b}$ \\
\hline
\end{tabular}

Common letters in a column are not significantly different at $5 \%$ level by DMRT

Grain yield of BR23 was significantly influenced by both irrigation water sources and fertilizer treatments (Table 3). Regarding Lalmota, grain yield was not significantly influenced by irrigation water sources but it was significantly influenced by fertilizers. The highest grain yield of 4.633 and $3.239 \mathrm{t} / \mathrm{ha}$ was recorded by tidal water in BR23 and Local Lalmota, respectively which was about 21 and $7 \%$ higher than the respective groundwater treatment. Regarding fertilizer treatments $\mathrm{P}$ omission or $\mathrm{P}$ addition gave identical yield. Interaction effects between irrigation water sources and fertilizers were not significant over both the varieties. Straw yield was significantly influenced by irrigation water sources and fertilizer treatments in both the rice varieties (Table 4). BR23 and Lalmota recorded about 6.0 and 6.5 t/ha straw yield, respectively in tidal water; where as it was 5.1 and $5.8 \mathrm{t} /$ ha in ground water treatments. About 1 ton higher straw yield was contributed by tidal water compared to ground water in both varieties. Remarkable variation was not found in P omitted or P added plots of Lalmota but it was significant in BR23.

Table 3. Percent sterility, 1000-grain weight (g) and grain yield (t/ha) of rice varieties as influenced by irrigation water sources and fertilizers, Aus 2009

Aman 2009 BR23

\begin{tabular}{|c|c|c|c|c|c|c|}
\hline \multirow[t]{2}{*}{ Treatments } & \multicolumn{2}{|c|}{ \%sterility } & \multicolumn{2}{|c|}{ 1000grain wt. } & \multicolumn{2}{|c|}{ Grain yield } \\
\hline & BR23 & Lalmota & BR23 & Lalmota & BR23 & Lalmota \\
\hline \multicolumn{7}{|l|}{ Irrigation } \\
\hline Tidal water & $17.20 \mathrm{~b}$ & 12.95 & 23.89 & 28.37 & $4.633 \mathrm{a}$ & 3.239 \\
\hline Ground water & $22.51 \mathrm{a}$ & 15.43 & 24.49 & 27.88 & $3.833 \mathrm{~b}$ & 3.034 \\
\hline \multicolumn{7}{|l|}{ Fertilizer } \\
\hline Control & 18.20 & 13.97 & $24.95 \mathrm{a}$ & $26.54 \mathrm{~b}$ & $2.738 \mathrm{~b}$ & $2.244 \mathrm{~b}$ \\
\hline $\mathrm{P}$ omission (NK) & 20.87 & 15.85 & $23.78 \mathrm{~b}$ & $28.90 \mathrm{a}$ & $5.007 \mathrm{a}$ & $3.479 \mathrm{a}$ \\
\hline NPK & 20.50 & 12.75 & $23.84 \mathrm{~b}$ & $28.95 \mathrm{a}$ & $4.953 \mathrm{a}$ & $3.686 \mathrm{a}$ \\
\hline \multicolumn{7}{|l|}{ Irrigation×Fertilizer } \\
\hline Tidal water $\times$ Control & 16.80 & 11.37 & 24.60 & 26.66 & 3.234 & 2.320 \\
\hline Tidal water $\times \mathrm{P}$ omission & 18.93 & 16.40 & 23.30 & 29.13 & 5.380 & 3.620 \\
\hline Tidal water $\times$ NPK & 15.87 & 11.07 & 23.76 & 29.33 & 5.284 & 3.776 \\
\hline Ground water $\times$ Control & 19.60 & 16.57 & 25.30 & 26.40 & 2.243 & 2.167 \\
\hline Ground water $\times \mathrm{P}$ omission & 22.80 & 15.30 & 24.25 & 28.67 & 4.633 & 3.339 \\
\hline Ground water×NPK & 25.13 & 14.43 & 23.92 & 28.56 & 4.623 & 3.597 \\
\hline
\end{tabular}

Common letters in a column are not significantly different at $5 \%$ level by DMRT 
Phosphorus content of rice grain and straw was significantly influenced by both irrigation water sources, fertilizer treatments, and interactions among them (Table 4). Tidal water always gave higher $P$ content than ground water. Phosphorus content was found higher when plants were fertilized with NPK. A general increasing trend of $P$ uptake by both the rice varieties were found in tidal water irrigation condition. BR23 uptake about 6,5 and $12 \mathrm{~kg} /$ ha more $\mathrm{P}$ from tidal water from absolute control, $\mathrm{P}$ omission and $\mathrm{P}$ addition treatments, respectively. Regarding Lalmota it was $0.5,6$, and $14 \mathrm{~kg} / \mathrm{ha}$, respectively. The results indicated that in control condition contribution of tidal submergence to $P$ uptake is controversial, but when plants received $\mathrm{N}$ and $\mathrm{K}$ they uptake more $\mathrm{P}$ from tidal water. Furthermore, highest $\mathrm{P}$ uptake due to tidal submergence was recorded when plants are applied with NPK fertilizers.

Table 4. Straw yield (t/ha), grain phosphorus (P) content (\%) and straw $P$ content (\%) of rice varieties as influenced by irrigation water sources and fertilizers, Aman 2009

\begin{tabular}{|c|c|c|c|c|c|c|}
\hline \multirow[t]{2}{*}{ Treatments } & \multicolumn{2}{|c|}{ Straw yield } & \multicolumn{2}{|c|}{ Grain P content } & \multicolumn{2}{|c|}{ Straw P content } \\
\hline & BR23 & Lalmota & BR23 & Lalmota & BR23 & Lalmota \\
\hline \multicolumn{7}{|l|}{ Irrigation } \\
\hline Tidal water & $6.028 \mathrm{a}$ & $6.457 \mathrm{a}$ & $0.296 \mathrm{a}$ & $0.286 \mathrm{a}$ & $0.155 \mathrm{a}$ & $0.153 \mathrm{a}$ \\
\hline Ground water & $5.095 \mathrm{~b}$ & $5.792 \mathrm{~b}$ & $0.269 \mathrm{~b}$ & $0.257 \mathrm{~b}$ & $0.098 \mathrm{~b}$ & $0.098 \mathrm{~b}$ \\
\hline \multicolumn{7}{|l|}{ Fertilizer } \\
\hline Control & $3.958 \mathrm{c}$ & $4.015 \mathrm{~b}$ & $0.276 \mathrm{~b}$ & $0.258 \mathrm{~b}$ & $0.098 \mathrm{~b}$ & $0.097 \mathrm{~b}$ \\
\hline $\mathrm{P}$ omission (NK) & $6.687 \mathrm{a}$ & $7.039 \mathrm{a}$ & $0.252 \mathrm{c}$ & $0.247 \mathrm{~b}$ & $0.092 \mathrm{~b}$ & $0.106 \mathrm{~b}$ \\
\hline NPK & $6.039 \mathrm{~b}$ & $7.320 \mathrm{a}$ & $0.319 \mathrm{a}$ & $0.309 \mathrm{a}$ & $0.190 \mathrm{a}$ & $0.174 \mathrm{a}$ \\
\hline \multicolumn{7}{|l|}{ Irrigation×Fertilizer } \\
\hline Tidal water $\times$ Control & $4.628 \mathrm{c}$ & 4.331 & $0.302 \mathrm{~b}$ & $0.260 \mathrm{c}$ & $0.105 \mathrm{bc}$ & $0.091 \mathrm{c}$ \\
\hline Tidal water $\times \mathrm{P}$ omission & $7.255 \mathrm{a}$ & 7.083 & $0.257 \mathrm{c}$ & $0.288 \mathrm{~b}$ & $0.102 \mathrm{c}$ & $0.122 \mathrm{~b}$ \\
\hline Tidal water $\times$ NPK & $6.201 \mathrm{~b}$ & 7.958 & $0.328 \mathrm{a}$ & $0.309 \mathrm{a}$ & $0.257 \mathrm{a}$ & $0.247 \mathrm{a}$ \\
\hline Ground water $\times$ Control & $3.289 \mathrm{~d}$ & 3.700 & $0.250 \mathrm{c}$ & $0.257 \mathrm{c}$ & $0.091 \mathrm{~cd}$ & $0.102 \mathrm{c}$ \\
\hline Ground water $\times \mathrm{P}$ omission & $6.118 \mathrm{~b}$ & 6.994 & $0.247 \mathrm{c}$ & $0.205 d$ & $0.081 \mathrm{~d}$ & $0.091 \mathrm{c}$ \\
\hline Ground water $\times$ NPK & $5.878 \mathrm{~b}$ & 6.682 & $0.309 \mathrm{~b}$ & $0.309 \mathrm{a}$ & $0.122 \mathrm{~b}$ & $0.102 \mathrm{c}$ \\
\hline
\end{tabular}

Common letters in a column are not significantly different at $5 \%$ level by DMRT

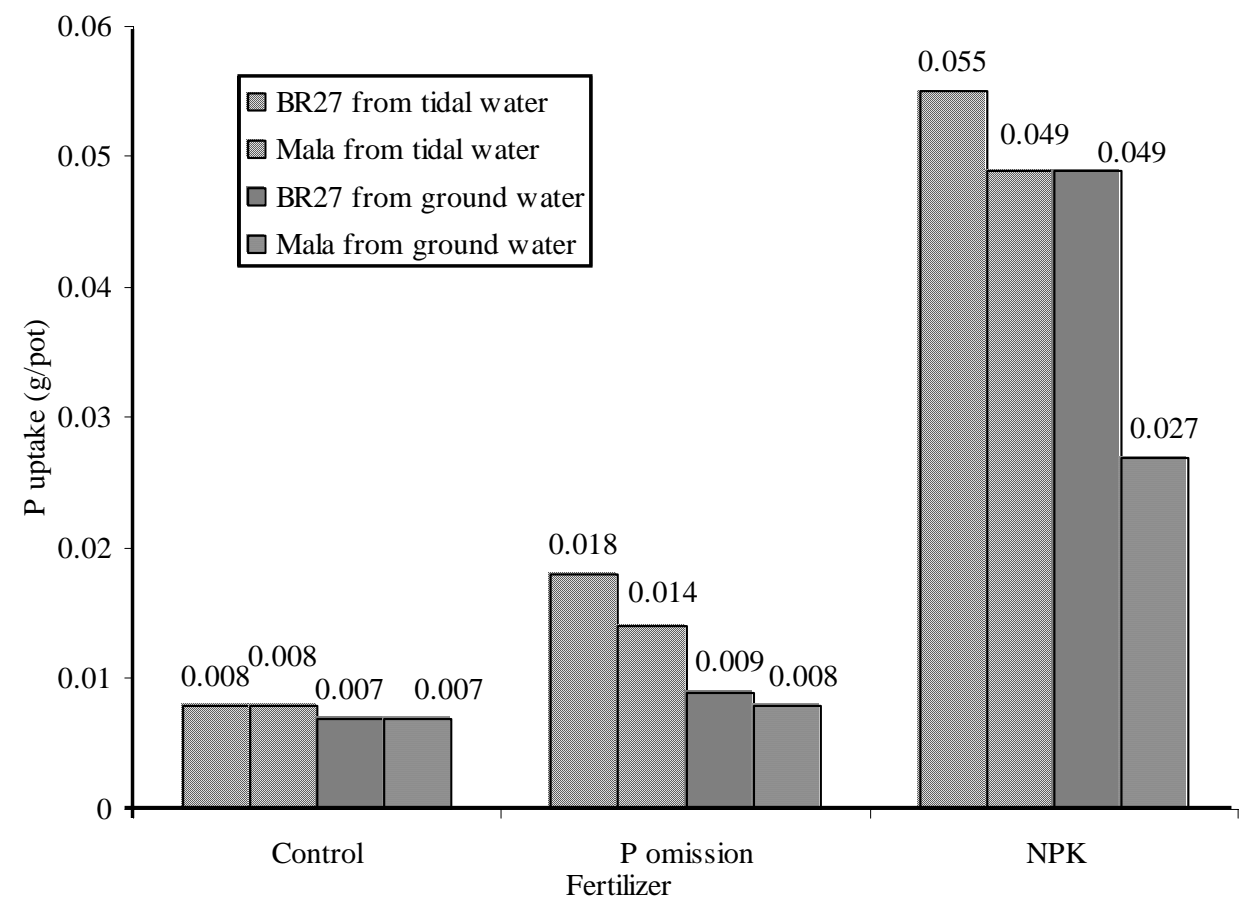

Fig. 1. Phosphorus uptake by two rice varieties from two irrigation water sources, Aus 2009 


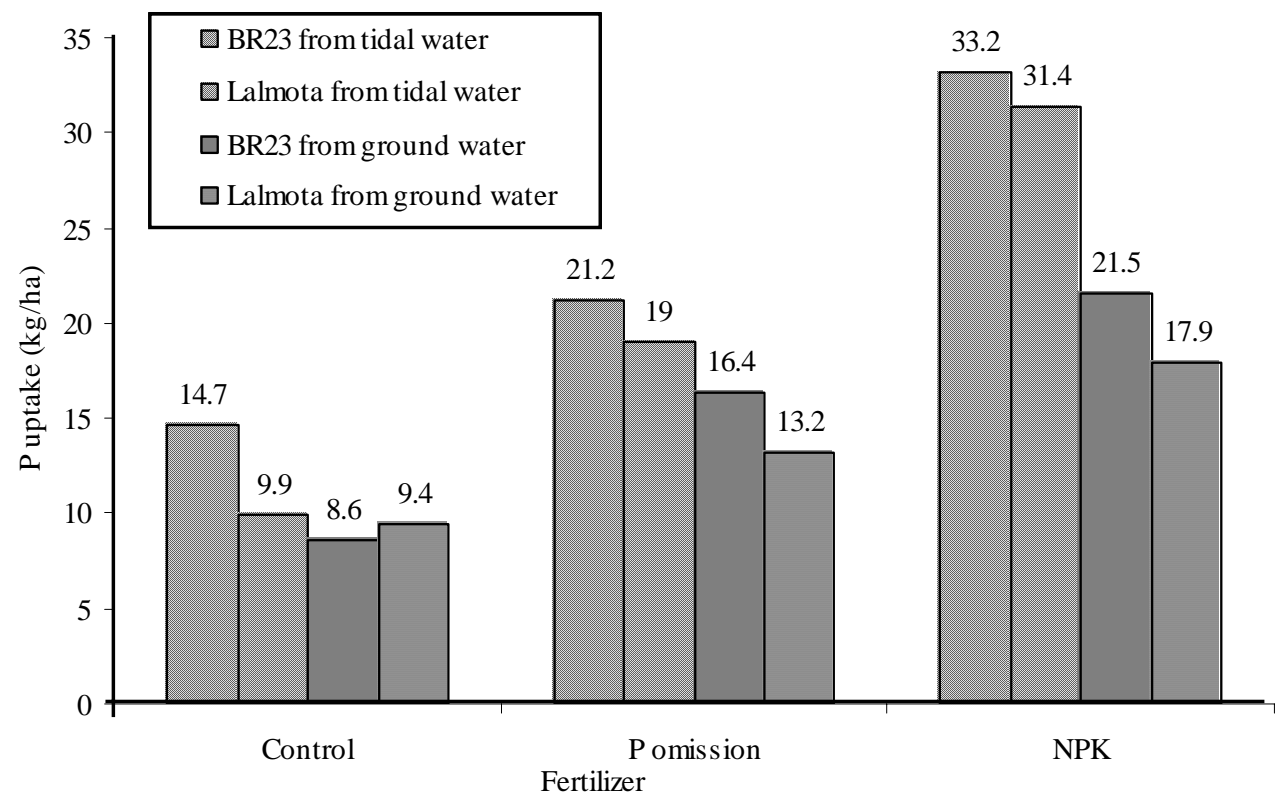

Fig. 2. Phosphorus uptake by two rice varieties from two irrigation water sources, Aman 2009

\section{Conclusion}

Tidal submergence is an important source of phosphorus. It increases all the growth parameters along with yield of rice. It supplies considerable quantities of phosphorus, however, it could not meet the total phosphorus requirement of rice.

\section{Acknowledgement}

I thank University Grants Commission, Bangladesh for financial support through the "Contribution of tidal sediments to soil fertility and crop yield" project to conduct the study.

\section{References}

Ali, M.M., Saheed, S.M., Kubota, D., Masunaga, T. and Wakatsuki, T. 1997. Soil degradation during the period 1967-1995 in Bangladesh. II. Selected chemical characters. Soil Sci. Plant Nutri. 43:879-890.

Darke, A.K. and Megonigal, J.P. 2003. Control of sediment deposition rates in two mid-Atlantic coast tidal freshwater wetlands. Estuarine, Coastal Shelf Sci. 57 (1-2): 259-272.

FRG (Fertilizer Recommendation Guide). 2005. Bangladesh Agricultural Research Council. Farmgate, Dhaka.

Haque, M.A., Khatun, A., Jharna, D.E. and Saleque, M.A. 2008. Effect of tidal water flooding on growth and nitrogen uptake of rice. Intl. J. BioRes. 5(2): 1-5.

Morse, J.L., Megonigal, J.P. and Walbridge M.R. 2004. Sediment nutrient accumulation and nutrient availability in two tidal freshwater marshes along the Mattaponi River, Virginia, USA. Biogeochemistry. 69: 175-206.

Odum, W.E. 1988. Comparative ecology of tidal freshwater and salt marshes. Ann. Rev. Ecol. Syst. 19: 147-176.

Saleque, M.A., Abedin, M.J., Panaullah, G.M. and Bhuyian, N.I. 1998. Yield and phosphorus efficiency of some lowland rice varieties at different levels of soil available phosphorus. Commun. Soil Sci. Plant Anal. 29: 2905-2916. 